\title{
Saprophytic flies in impacted areas of the Belo Monte Dam, Pará, Brazil (Diptera: Mesembrinellidae, Neriidae, Ropalomeridae, and Sarcophagidae): community composition, abundance, and species richness
}

\author{
Camila Lorena Damasceno Queiroz ${ }^{1 \oplus}$, Caroline Costa De-Souza ${ }^{(\oplus)}$, Hermes Fonseca de Medeiros ${ }^{3(}$, \\ William Leslie Overal $^{\circledR}{ }^{\circledR}$, Arleu Barbosa Viana-Junior ${ }^{\circledR}$,Fernando da Silva Carvalho-Filho $^{1}{ }^{\circledR}$ \\ ${ }^{1}$ Museu Paraense Emílio Goeldi, Coordenação de Zoologia, Belém, PA, Brasil. \\ ${ }^{2}$ Museu Paraense Emílio Goeldi, Programa de Pós-Graduação em Zoologia, Coordenação de Zoologia, Belém, \\ PA, Brasil. \\ ${ }^{3}$ Universidade Federal do Pará, Campus Universitário de Altamira, Altamira, PA, Brasil. \\ *Corresponding author: Fernando S. Carvalho-Filho, e-mail: fernanbio@yahoo.com.br
}

QUEIROZ, C.L.D, DE-SOUZA, C.C, MEDEIROS, H.F., OVERAL, W.L., VIANA-JUNIOR, A.B., CARVALHO FILHO, F.S Saprophytic flies in impacted areas of the Belo Monte Dam, Pará, Brazil (Diptera: Mesembrinellidae, Neriidae, Ropalomeridae, and Sarcophagidae): community composition, abundance, and species richness. Biota Neotropica 21(1): e20201026. https://doi.org/10.1590/1676-0611-BN-2020-1026

\begin{abstract}
The present study aims to document the community composition, abundance, and species richness of saprophytic fly species (Mesembrinellidae, Neriidae, Ropalomeridae, and Sarcophagidae) of the Volta Grande region of the Xingu River, a poorly sampled area impacted by the Belo Monte hydroelectric dam. Five collecting trips were carried out between 2014 and 2016, when traps baited with fermenting bananas were used. A total of 154 specimens, three genera, and six species were collected of Mesembrinellidae; 196 specimens, three genera, and seven species of Neriidae; 272 specimens, three genera, and six species of Ropalomeridae; and 624 specimens, 22 species and 10 genera of Sarcophagidae. Species accumulation curves for all families except Sarcophagidae demonstrated a strong tendency towards stabilization, showing that sampling efforts were sufficient to record most of the targeted species. Laneela perisi (Mariluis, 1987) (Mesembrinellidae) is a new record for the state of Pará. Among Ropalomeridae, Apophorhynchus amazonensis Prado, 1966, is a new record for Pará. Among Sarcophagidae, Helicobia aurescens (Townsend, 1927) is newly recorded from the Brazilian Amazon, and Ravinia effrenata (Walker, 1861) and Titanogrypa larvicida (Lopes, 1935) are new records for Pará.
\end{abstract}

Keywords: anthropic impact, insect, invertebrate, tropical forest.

\section{Moscas saprofíticas na área sob influência da barragem de Belo Monte, Pará, Brasil (Diptera: Mesembrinellidae, Neriidae, Ropalomeridae e Sarcophagidae): composição, abundância e riqueza de espécies}

Resumo: O presente estudo teve como objetivo documentar a composição, abundância e riqueza das espécies de moscas saprófitas (Mesembrinellidae, Neriidae, Ropalomeridae e Sarcophagidae) da Volta Grande do rio Xingu, uma área pouco amostrada e impactada pela Hidrelétrica Belo Monte. Foram realizadas cinco expedições de coleta entre 2014 a 2016, quando foram utilizadas armadilhas contendo banana em fermentação como isca. Foram coletados 154 espécimes, três gêneros e seis espécies de Mesembrinellidae; 196 espécimes, três gêneros e sete espécies de Neriidae; 272 espécimes, três gêneros e seis espécies de Ropalomeridae; e 624 espécimes, 22 espécies e 10 gêneros de Sarcophagidae. As curvas de acumulo de espécies para todas as famílias, exceto Sarcophagidae, demonstraram uma forte tendência à estabilização, mostrando que o esforço amostral foi suficiente para registrar a maioria das espécies-alvo. Laneela perisi (Mariluis, 1987) (Mesembrinellidae) é um novo registro para o estado do Pará. Entre os Ropalomeridae, Apophorhynchus amazonensis Prado, 1966, é um novo registro para o Pará. Em relação aos Sarcophagidae, Helicobia aurescens (Townsend, 1927) é um novo registro para a Amazônia Brasileira e Ravinia effrenata (Walker, 1861) e Titanogrypa larvicida (Lopes, 1935) são novos registros para o Pará.

Palavras-chave: impacto antrópico, inseto, invertebrado, floresta tropical. 


\section{Introduction}

Biological inventories are essential for recording and describing the local biodiversity of some taxa from a given area, at a determined time and space where this information is lacking (Silveira et al. 2010), representing the first step towards the creation of an effective biodiversity conservation strategy and rational use of the environments (Margules \& Austin 1991, Kim 1993, Santos 2003). In some cases, these inventories represent the only information available on the biota of an altered area or the historical record of previous occurrences of a given taxon (Tonetti et al. 2017). They are also the source of new species and new records (Brown et al. 2018). In addition, standardized inventories are the baseline for successful monitoring programs, which are a useful tool to evaluate rates of change of natural populations (Morrison et al. 2008, Silveira et al. 2010). As the data produced by inventories are essential to the establishment of sound conservation plans (Santos 2003), they should preferably be performed in places where the biota is, to some degree, extirpated or vulnerable to extinctions (Kim 1993) or where high species richness, endemism, or biogeographic and phylogenetic significance can be found (Erwin 1991, Vane-Wright et al. 1991, Kim 1993).

The Amazon basin of Brazil corresponds to about 6 million $\mathrm{km}^{2}$, where approximately $10 \%$ of known animal and plant species occur, making it one of the most biodiverse tropical forests on the planet (Silva $\&$ Garda 2011). This diversity, however, is threatened due to anthropic impacts from activities such as deforestation (Vieira et al. 2008), cattle ranching (Barona et al. 2010), and hydroelectric dam construction (Alho et al. 2011). However, considering the geographic extension of this region and the rates of environmental changes, there are proportionally few studies on its biota and these are usually concentrated near research centers and access routes (e.g. roads, large rivers) (Oliveira et al. 2016). One of the most impacting projects in the history of the Amazon is the Belo Monte hydroelectric dam, located on the Xingu River, in northern Brazil (Fearnside 2006, Tófoli et al. 2017). Since its construction, this hydroelectric dam has caused many drastic environmental changes in terrestrial and aquatic habitats, but the full impacts will take time to manifest (Tófoli et al. 2017). This is of special concern because the biota of Xingu region is still little-known, and many taxa of this region are endemic (Lujanand \& Conway 2015, Pérez 2015, Tófoli et al. 2017).

Inventories of terrestrial fauna are usually carried out on taxonomic groups that are both diverse and abundant taxa, easy to collect, and relatively easy to identify, such as vertebrates, butterflies, especially frugivores, and ants (Freitas et al. 2003, Santos 2003). However, other groups of insects also exhibit these characteristics, such as some dipteran families. Diptera is one of the most diverse orders of insects, with about 160,000 described species worldwide (Pape et al. 2011), and one of the most ecologically diverse (Marshall 2012). Some dipteran families are saprophytic, feeding mainly on rotting fruits, such as Mesembrinellidae, Neriidae, and Ropalomeridae (Guimarães 1977, Buck 2010, IbanezBernal 2010, Gomes et al. 2013). Even Sarcophagidae, which most species feed on dead animals, are commonly found visiting rotting fruits (Lopes 1975, Pape \& Dahlem 2010). The species of these families are suitable organisms for comprehensive biodiversity inventories because they are abundant in baited traps and are relatively easy to identify, mainly due to the publication of taxonomic revisions with keys to genera and species, such as for the Mesembrinellidae (Guimarães 1977, Bonnato 2001, Kosmann et al. 2013), Neriidae (Sepúlveda et al. 2013a, b, 2014), and Ropalomeridae (Marques \& Ale-Rocha 2005, Marques-Costa \& Ale-Rocha 2005, Alves \& Ale-Rocha 2006, Kirst \& Ale-Rocha 2012).

Therefore, the main goal of this study is to provide the first comprehensive description of the composition, species richness, and geographical distribution of the fauna of saprophytic flies obtained with a standardized protocol in forested environments in the Volta Grande of the Xingu River, an area impacted by the Belo Monte hydroelectric dam. These data will be useful in long-term monitoring studies, helping to understand changes in the community of four families of Diptera caused by the construction of a major hydroelectric dam.

\section{Material and Methods}

\section{Area of study}

The study was carried out in the Direct Influence Area (AID) of the Belo Monte hydroelectric dam, located between lower and middle Xingu River, covering five municipalities in the state of Pará: Altamira, Anapú, Brasil Novo, Senador José Porfírio, and Vitória do Xingu (Figure 1) (Salomão et al. 2007). The region is located in the Amazon biome, with original vegetation classified as dense ombrophilous forest, as well as floodplain forests on river banks (IBGE, 2012). Regional climate is classified as type Am, according to the Køppen system, with a mean annual temperature of $26^{\circ} \mathrm{C}$, annual precipitation of $2.289 \mathrm{~mm}$, and relative humidity between $78 \%$ and $88 \%$ (Sousa-Junior et al. 2006). Rainfall presents intense seasonal variations, with wet season between December and May and dry season during the other months of the year (Santos et al. 2015).

\section{Collection, taxonomy, and preparation of samples}

Insect samples from the "Terrestrial Ecosystem Monitoring Project" of the Belo Monte hydroelectric dam were utilized in this study. The sample design is based on eight "RAPELD" modules (Magnusson et al. 2005). Each module is composed of two parallel transects $5 \mathrm{~km}$ long, separated by $1 \mathrm{~km}$ (Figure 1). From each transects six side trails each $250 \mathrm{~m}$ long, were established. The side trails accompany relief contour lines, so they are sinuous rather than straight. Geographic coordinates of the eight modules are as follows: 0340'37'S, 52 30'39'W (Module

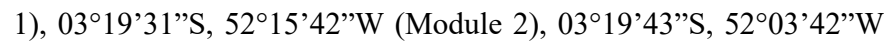

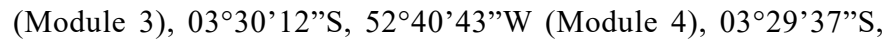

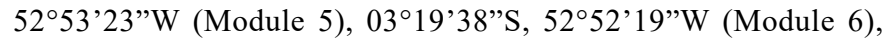

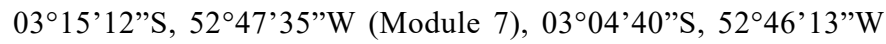
(Module 8).

Five collection campaigns were carried out between 2014 and 2016. The first was in July 2014; the second in January and February 2015; the third in July and August 2015; the fourth in February and March 2016, and the fifth in July 2016.

Samples were collected using fruit-fly traps (Medeiros \& Klazko 1999) made from 2-liter plastic bottles on which insects could enter through four openings of 2.5 by $0.5 \mathrm{~cm}$. In each trail four traps were placed, the first at $10 \mathrm{~m}$ from the main trail, the second at $90 \mathrm{~m}$, the third at $150 \mathrm{~m}$, and the fourth at $250 \mathrm{~m}$. Fermenting bananas used as bait were crushed and mixed with $1 \%$ dry bakers' yeast (Saccharomyces cerevisiae) and fermented for 36 hours. Traps were left open in the field 


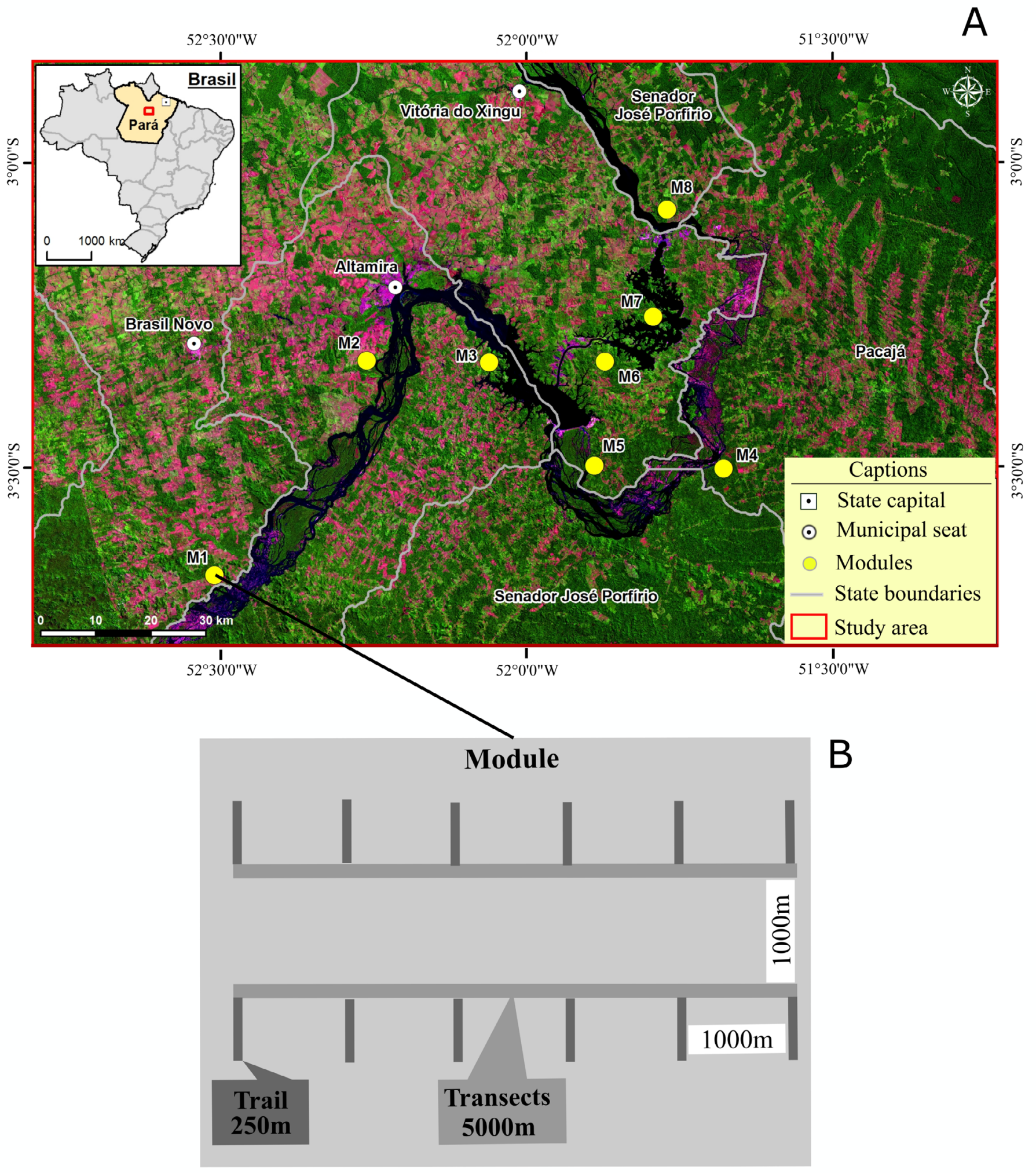

Figure 1. A. Location of the study area, on the middle Xingu River, in the Belo Monte area, Pará, Brazil. B. Schematic illustration of the sampling protocol. 
for 48 hours, and every 24 hours insects were removed and the bait exchanged for freshly fermented banana mash.

Initially, collected insects were frozen before being passed to $90 \%$ ethyl alcohol after preliminary sorting. At the entomology laboratory in the Museu Paraense Emílio Goeldi (MPEG) insects were further sorted and all specimens of Sarcophagidae, Neriidae, Mesembrinellidae, and Ropalomeridae were pinned and labeled, except for the Sarcophagidae, where only male specimens were mounted and counted. The flies (pinned and in alcohol) are deposited in the entomological collection of MPEG.

Fly specimens were identified to species level with identification keys and by comparison with identified specimens in the MPEG collection. For the identification of Mesembrinellidae, keys were used from Guimarães (1977), Bonatto (2001), and Kosmann et al. (2013); for Neriidae the keys were by Carvalho-Filho \& Esposito (2008) and Sepúlveda et al. (2006a, b); for Ropalomeridae the keys were by Prado (1966), Marques \& Ale-Rocha (2005), Marques-Costa \& Ale-Rocha (2013), Ale-Rocha \& Alves (2006), and Kirst \& Ale-Rocha (2012); and for Sarcophagidae the keys and other taxonomic tools were by Lopes (1939, 1946, 1985, 1987), Lopes \& Tibana (1987), Tibana \& Xerez (1985), Carvalho \& Mello-Patiu (2008), Carvalho-Filho \& Esposito (2012), and Buenaventura \& Pape (2013). Only male specimens of Sarcophagidae were identified at specific level, since identification is based mainly on features of male genitalia.

\section{Ecological analyses}

Side trails were considered to be sample units, and samples consisted of all captures in the trail over all collection periods. In this way, there were 16 transects with 96 samples. In order to evaluate if the sample effort was sufficient to estimate species richness in the area, Chao1, Chao2, Jackknife1 (first order Jackknife), Jackknife2 (second order Jackknife), ICE, ACE, and Bootstrap were calculated with EstimateS 9.0 (Colwell 2013). Values obtained for different estimators were not discrepant, so only Jackknife1 was used, which is a strong estimator based on abundances and takes into account rare species, i.e., singletons and doubletons (species represented by one or two individuals, respectively); uniques and duplicates (number of species occurring in a single sample and two samples, respectively) (Colwell \& Coddington 1994).

\section{Results}

In total, 1246 specimens were identified of those collected in traps baited with rotting bananas in Belo Monte, as follows: Mesembrinellidae (154 specimens), Neriidae (196), Ropalomeridae (272), and Sarcophagidae (624). Among these, one Sarcophagidae (Helicobia aurescens (Townsend, 1927)) is newly recorded from the Brazilian Amazon, and five species are new records for the state of Pará: Laneela perisi (Mariluis, 1987) (Mesembrinellidae), Apophorhynchus amazonensis Prado, 1966 (Ropalomeridae), Ravinia effrenata (Walker, 1861), and Titanogrypa larvicida (Lopes, 1935) (Sarcophagidae).

\section{Mesembrinellidae}

Six species and three genera of Mesembrinellidae were collected (Table 1). The largest genus was Mesembrinella with three species, and Laneella was the least species-rich with only one species (Table 1). The three most abundant species were Mesembrinella bicolor (Fabricius, 1805) (74\% of all Mesembrinellidae specimens collected), Eumesembrinella quadrilineata (Fabricius, 1805) (19\%), and Laneella perisi (Mariluis, 1987) (12\%). The least abundant species was Mesembrinella belardiana (Aldrich, 1922), with only two specimens (Table 1).

Analysis of species richness estimated seven Mesembrinellidae species, compared with an observed richness of six species (Figure 2A). In order to verify the efficiency of the sampling, the behavior of the rare species in the samples was observed. There were one unique, one singleton, one doubleton, and one duplicate for Mesembrinellidae. The species accumulation curve showed a strong tendency towards stabilization, indicating that the collection effort was sufficient to inventory the Mesembrinellidae (Figure 2A). The uniques and doubletons curves of Mesembrinellidae also showed a tendency to stabilize (Figure 2B).

\section{Neriidae}

Three genera and seven species of Neriidae were collected (Table 1). The most species-rich genera were Glyphidops, with four species, and Nerius, with two species (Table 1). The most abundant species were Glyphidops filosus (Fabricius, 1805), with $77 \%$ of Neriidae specimens, and Nerius pilifer Fabricius, 1805, with $27 \%$ (Table 1). Abundances of the remaining species totaled less than $10 \%$. The least abundant species were Glyphidops flavifrons (Bigot, 1886) and Glyphidops vittatus (Cresson, 1912), each with only one specimen (Table 1).

As for the behavior of rare species in the sample, two uniques, two singletons, no doubletons and no duplicates were collected. The species accumulation curve showed a strong tendency towards stabilization (Figure 3A), but this was not observed for the curves of uniques, singletons, doubletons, and duplicates (Figure 3B). Despite the lack of stabilization of the rare species curves, an estimate of nine species was obtained, only two more than the number collected (Figure 3A), indicating that the sampling effort was sufficient to record most of the species of the locality.

\section{Ropalomeridae}

Six species and three genera of Ropalomeridae were collected (Table 1). The largest genus was Ropalomera with four species, but the abundance of each species was equal to or less than two individuals (Table 1). Only one species of Willistoniella, W. pleuropunctata (Wiedemann, 1824) was collected, and this was the most abundant species ( $97.4 \%$ of collected specimens).

Analysis of the patterns of species incidence and abundance for Ropalomeridae estimated eight species, as opposed to an observed richness of six species (Figure 4A). As for the behavior of the rare species, two uniques, two singletons, one doubleton, and one duplicate were collected. The species accumulation curve showed a strong tendency towards stabilization (Figure 4A), indicating that sampling effort was sufficient to document the local fauna. Curves for uniques and singletons were stabilized, whereas doubletons and duplicate curves appear to have not reached stability for Ropalomeridae (Figure 4B). 
Table 1. Community composition and species abundances of saprophytic flies in the study area, on the middle Xingu River, in the Belo Monte direct impact area, PA, Brazil (families Mesembrinellidae, Neriidae, Ropalomeridae and Sarcophagidae).

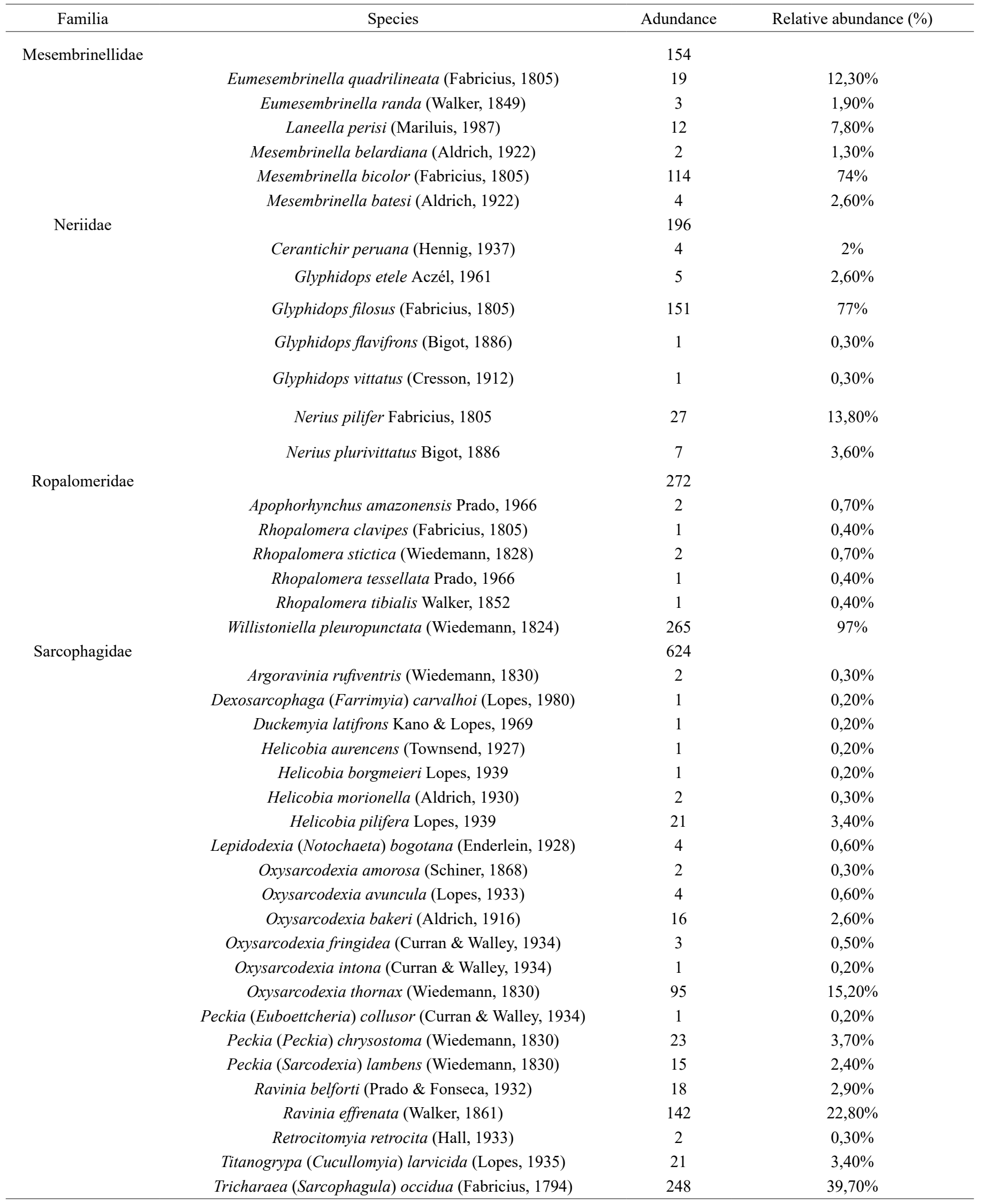



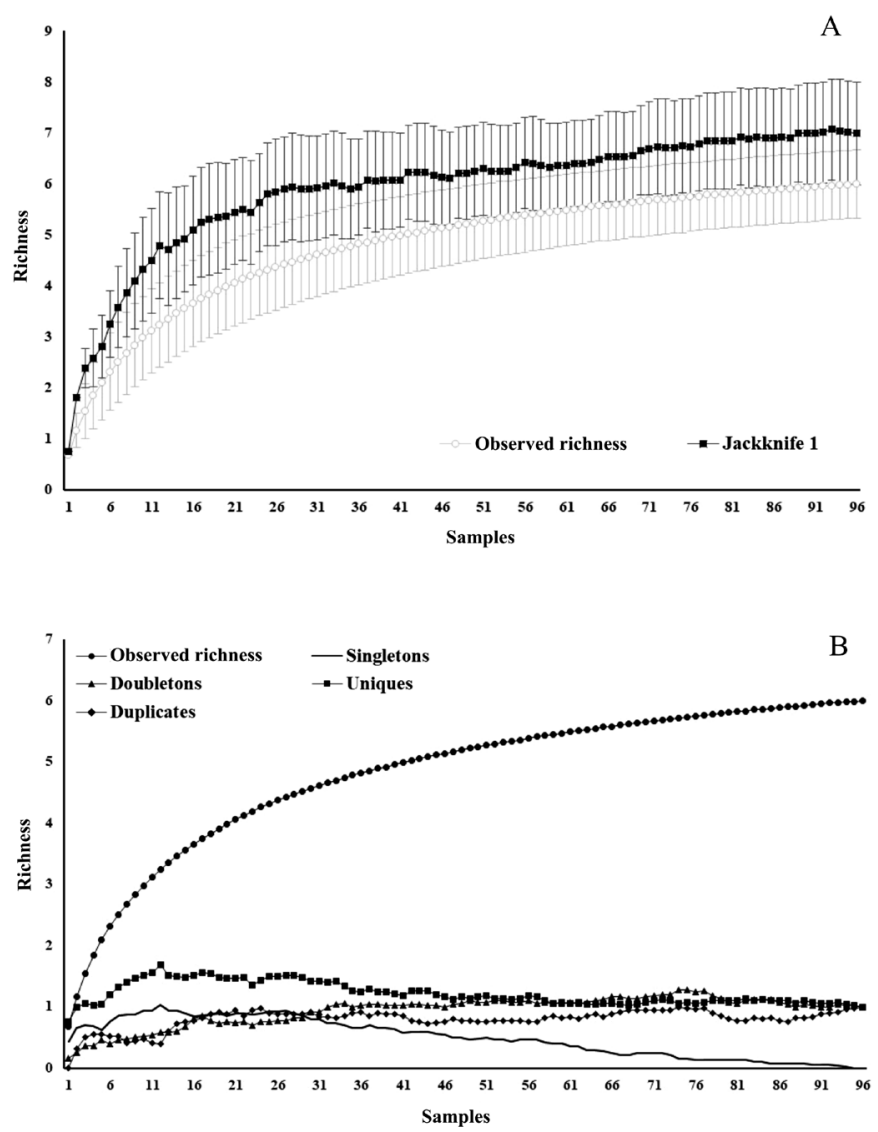

Figure 2. Mesembrinellidae. A. Species accumulation curve (observed richness [Mao Tau] and estimated species richness [Jackknife1]). B. Rare species richness estimation.

\section{Sarcophagidae}

Sarcophagidae was the most abundant family with 624 specimens in at least 11 genera and 22 species (Table 1). The most species-rich genera were Oxysarcodexia (six species) and Helicobia (four species). The genera with only one species each were Argoravinia, Dexosarcophaga, Duckemyia, Lepidodexia, Titanogrypa, and Tricharaea. Despite this, Tricharaea (Sarcophagula) occidua (Fabricius, 1794) was the most abundant species, with $39.7 \%$ of collected specimens (Table 1). The second most abundant species was Ravinia effrenata (Walker, 1861), with $22.8 \%$ of collected specimens (Table 1 ).

Analysis of species incidence and abundance patterns for Sarcophagidae estimated 28 species, as opposed to an observed richness of 22 species (Figure 5A). As for the behavior of the rare species, four uniques, five singletons, five doubletons, and six duplicates were collected in the samples. The species accumulation curve did not reach the asymptote (Figure 5B), indicating that sampling effort was not sufficient to fully document the local fauna. Curves of uniques and singletons stabilized, whereas doubletons and duplicate curves appear not to have reached stability for Sarcophagidae (Figure 5A).

\section{Discussion}

Species accumulation curves for all families except Sarcophagidae demonstrated a strong tendency towards stabilization, showing that
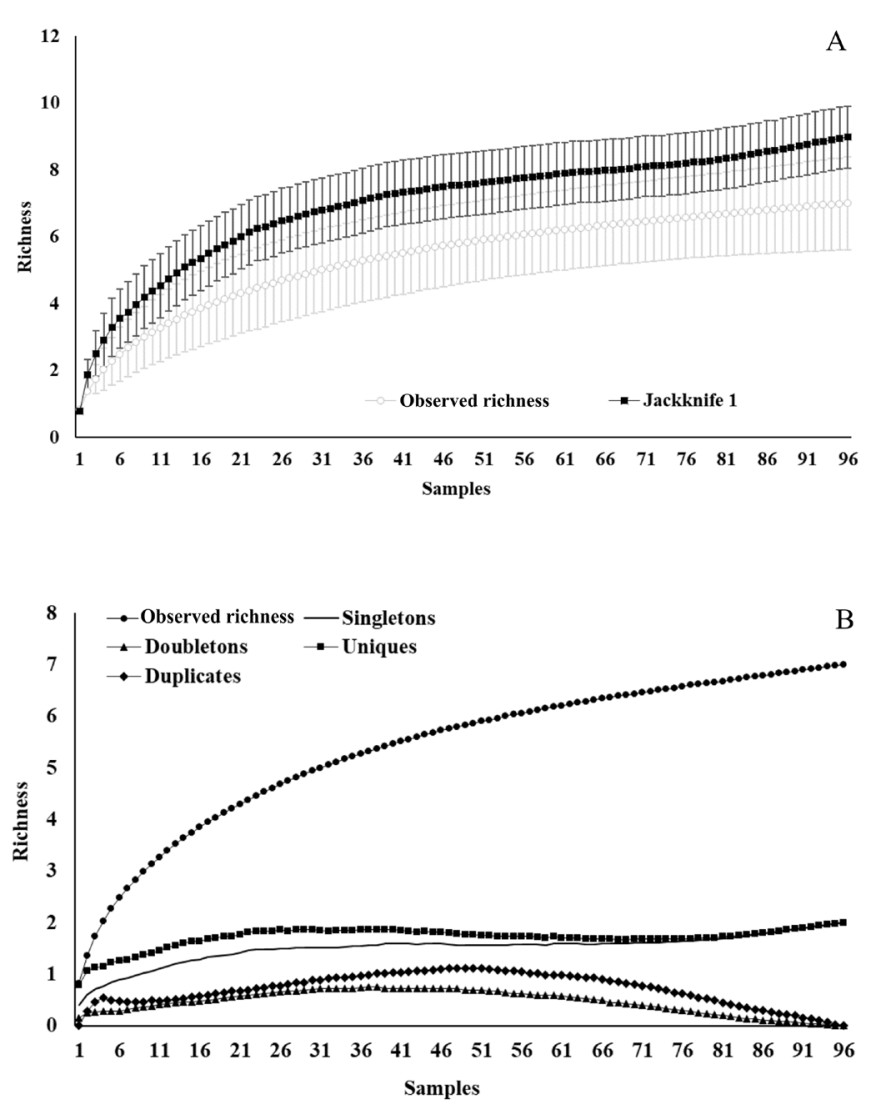

Figure 3. Neriidae. A. Species accumulation curve (observed richness [Mao Tau] and estimated species richness [Jackknife1]). B. Rare species richness estimation.

sampling efforts were sufficient to record most of the targeted species. This result indicates that traps baited with rotting fruit are effective in inventories of Mesembrinellidae, Ropalomeridae, and Neriidae. Nonstabilization of the species accumulation curve of Sarcophagidae has also been observed in studies performed in Brazil utilizing traps baited with carrion (Souza et al. 2011, 2015), and it may be related to the great number of species in the tropical environments (Pape 1996).

The six fly species newly reported from state of Pará reinforce the need for more research on the biodiversity in the Xingu region and other poorly sampled areas of the state. Pará is the second largest state in Brazil and one with the greatest levels of deforestation and forest degradation of the Brazilian Amazon (Fonseca et al. 2015). The loss or drastic degradation of natural vegetation in this state could cause the local or overall extinction of some species of invertebrates, even before they are properly studied taxonomically or ecologically and even before they are formally reported for the region.

In all the ecological studies published on Mesembrinellidae carried out in the Amazon, only the genera Eumesembrinella and Mesembrinella have been recorded (Esposito \& Linhares 2002, Amat 2010, Esposito et al. 2010, Gomes et al. 2013, Amat et al. 2016). In the present study, a species of the genus Laneella, L. perisi (Figure 6A) was also collected, as the third most abundant species of its family (Table 1). This difference may be related to the kind of bait utilized, since in the other studies performed in the Amazon, rotting beef lung was utilized 

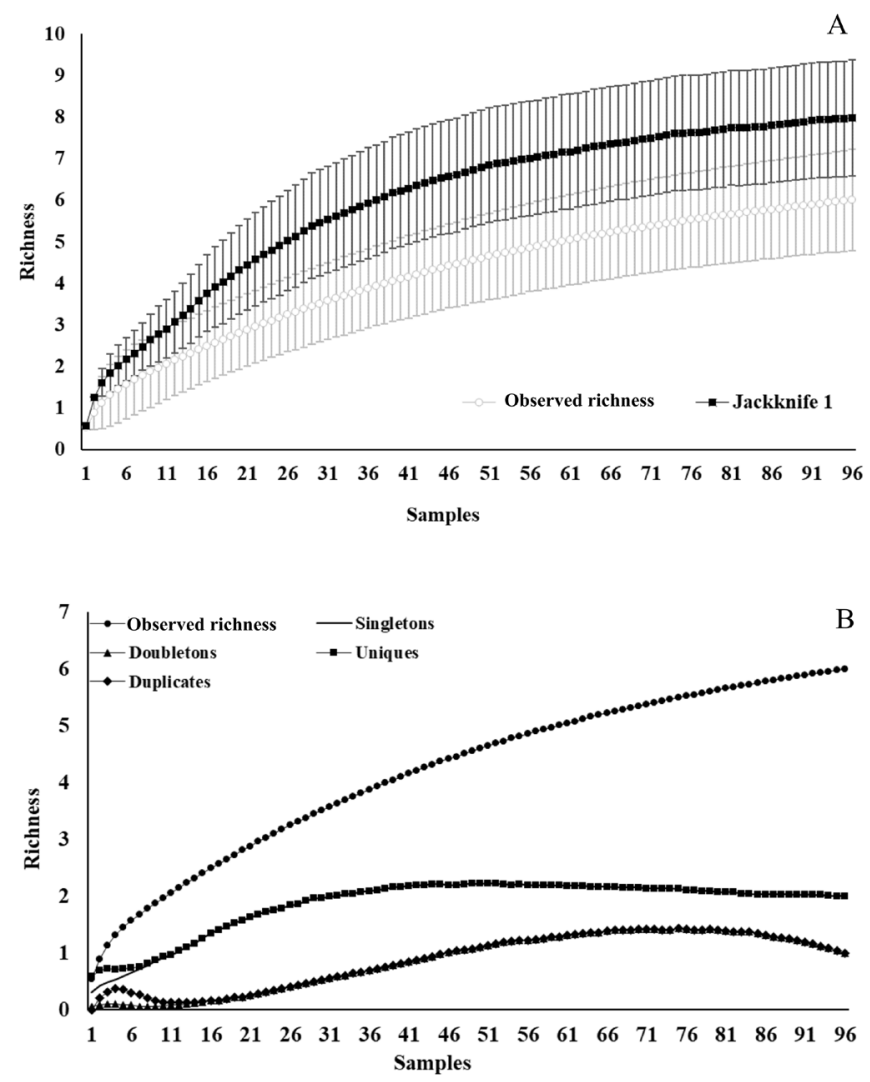

Figure 4. Ropalomeridae. (A) Species accumulation curve (observed richness [Mao Tau] and estimated species richness [Jackknife1]); (B) Rare species estimation.

as bait. However, Gomes et al. (2013) also used banana-baited traps in the Caxiuanã National Forest, but they did not collect $L$. perisi.

In ecological studies undertaken in southeastern Brazil, the three reported genera were also found in this study, but the Laneella species collected there was L. nigripes (Guimarães, 1977) (Ferraz et al. 2010, Barbosa et al. 2014). Laneella perisi has been recorded for Colombia and Ecuador (Wolff et al. 2012) and in Brazil for the state of Rondônia (Bonatto 2001), but it is nevertheless widely distributed throughout the Brazilian Amazon (Carvalho-Filho et al., in preparation). Therefore, this is a new record for the state of Pará. Most likely, L. perisi is associated with the Amazonian biome and L. nigripes with the Brazilian Atlantic Forest. In the study by Ferraz et al. (2010), undertaken in the Tinguá Reserve, state of Rio de Janeiro, the most abundant species of Mesembrinellidae was L. nigripes, while studies in the Amazon indicate the most abundant species as Eumesembrinella randa (Esposito \& Linhares 2002, Amat 2010, Esposito et al. 2010, Souza et al. 2015, Amat et al. 2016). In the present study, however, the most abundant species was Mesembrinella bicolor, while only three specimens of $E$. randa were collected (Table 1).

The genus Mesembrinella has 13 described species (Guimarães 1977), but only the three collected in this study have been reported from carrion baits in other Amazonian localities, where M. bellardiana is generally the most abundant species, followed by the less abundant $M$. bicolor (Esposito \& Linhares 2002; Amat 2010, Esposito et al. 2010,
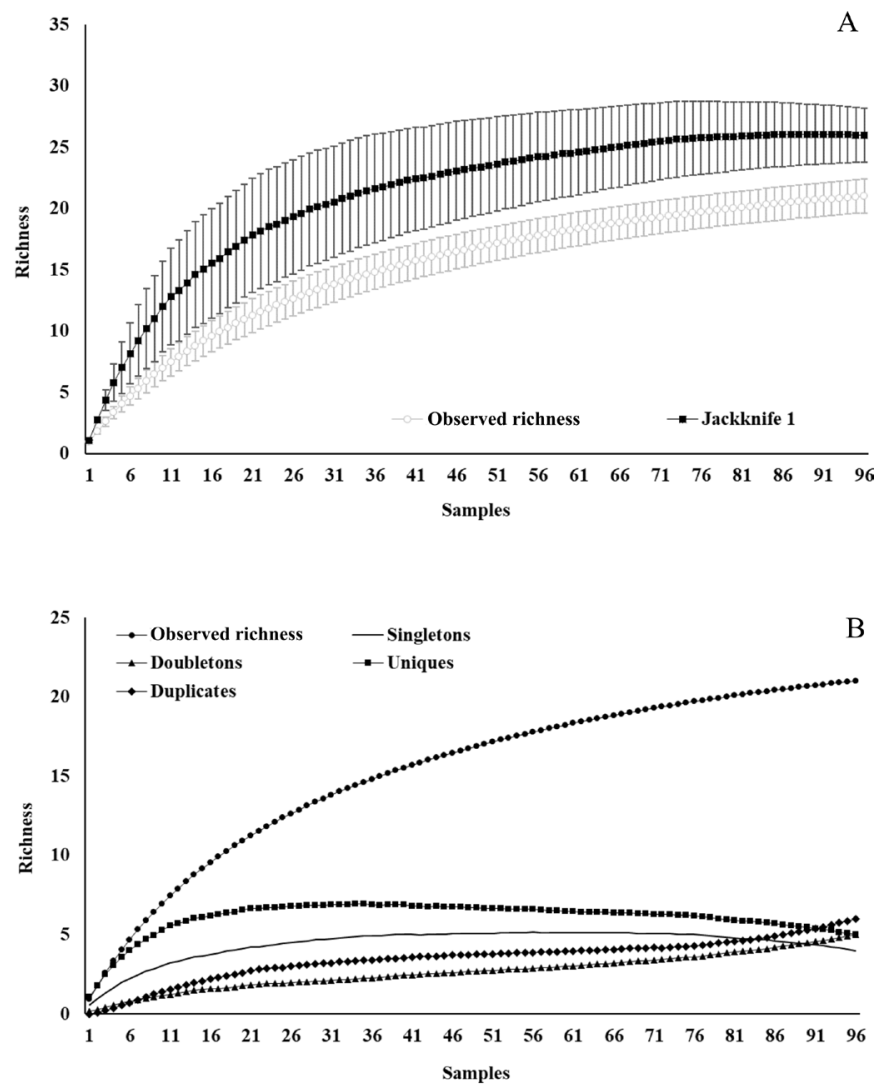

Figure 5. Sarcophagidae. (A) Species accumulation curve (observed richness [Mao Tau] and estimated species richness [Jackknife1]); (B) Rare species richness estimation.

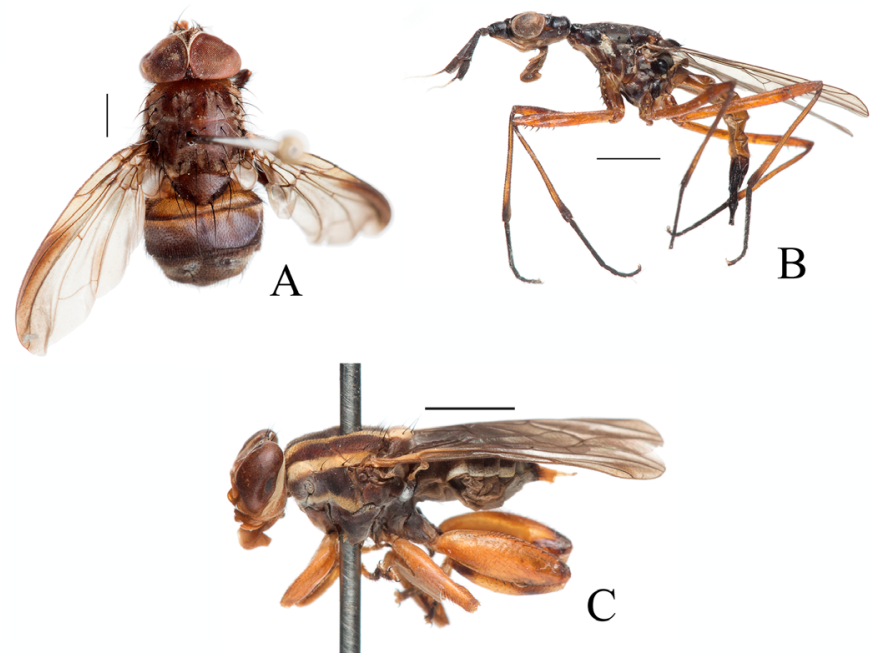

Figure 6. A. Laneella perisi, dorsal view. B. Cerantichir peruana, lateral view. C. Apophorhynchus amazonensis, lateral view. Scale bars $=2 \mathrm{~mm}$. Photos by C.A.C. Favacho.

Gomes et al. 2013, Amat et al. 2016). These three species are widely distributed in forested habitats in Brazil (Guimarães 1977) where, as observed in ecological studies, they are the most abundant species making them an important component of the fauna of Mesembrinellidae. 
The genus Eumesembrinella contains four described species (Guimarães 1977, Bonatto 2001), but only two were collected in this study, as they were in other ecological studies in the Amazon (Esposito \& Linhares 2002, Amat 2010, Esposito et al. 2010, Gomes et al. 2013, Amat et al. 2016). In these studies, E. randa is usually the most abundant species, a pattern observed in Belo Monte as well (Table 1). This species is very common in primary and secondary forests, but this has not been observed for E. quadrilineata (Carvalho-Filho et al., in preparation), suggesting that $E$. randa is a habitat generalist and possibly a competitor in regard to E. quadrilineata.

Despite recent advances in the taxonomy of Neotropical Neriidae (Sepúlveda et al. 2013a, b, 2014), no study on the community composition, abundance, and species richness of this family has been published until now. Studies on the taxonomy and systematic of Neriidae were based on specimens deposited in natural history museum that were obtained in sporadic and non-systematized collections.

Most neriid species collected in this study belong to the genus Glyphidops Enderlein, 1922, which is the most species-rich in the Neotropical region, with 14 described species (Sepúlveda et al. 2014). The most abundant species was G. filosus, with $77 \%$ of the collected specimens (Table 1). The least abundant species were G. flavifrons and G. vittatus, each with one specimen (Table 1). The species G. filosus presents a wide geographical distribution, ranging from Central America (Honduras) to southern Brazil (Sepúlveda et al. 2014) and is one of the most numerous species in collections of Neriidae (Carvalho-Filho \& Esposito 2008, Sepúlveda et al. 2014). This could be the most abundant species of Glyphidops and all of Neriidae throughout their distribution. However, more ecological studies on this family are needed to see if this pattern holds for other localities in the Neotropical region.

Nerius (Fabricius, 1805) has 10 described species (Aczél 1961, Steyskal 1968) with two in the Brazilian Amazon (Carvalho-Filho \& Esposito 2008) that were collected in this study, of which N. pilifer was the second most abundant species of the family (Table 1). Glyphidops flosus and N. pilifer are both widely distributed species that have been collected in primary and secondary forests, plantations, and even urban gardens (Carvalho-Filho et al., in preparation).

Cerantichir peruana (Figure 6B) have been reported from Brazil (Acre and Pará) by Carvalho-Filho \& Esposito (2008) and later also registered for Rondônia and Mato Grosso (Sepúlveda et al. 2013a). This species is rarely collected in Brazil, and few specimens are deposited in Brazilian collections (eight in MPEG and three in the Jesus Santiago Moure Entomological Collection of the Federal University of Paraná) (Carvalho-Filho \& Esposito 2008, Sepúlveda et al. 2013a).

Most of the collected specimens of Ropalomeridae (97.4\%) belong to $W$. pleuropunctata. The genus Willistoniella Mik, 1895 has four described species (Marques \& Ale-Rocha, 2005), but only one, W. pleuropunctata, was collected in this study. This species has a wide geographical distribution, ranging from Mexico to Argentina (Marques \& Ale-Rocha, 2005). In a study on the population variation of Ropalomeridae in Manaus, two genera, Ropalomera Wiedemann, 1824 and Willistoniella, were collected, and $92 \%$ of the specimens belonged to the genus Willistoniella (Marques et al. 2004), suggesting that species of this genus, especially $W$. pleuropunctata, may be the most abundant Ropalomeridae in several parts of the Amazon, a fact that may be related to the generalist habit of the species (Marques et al. 2004).
In the study by Marques et al. (2004), all four species of Willistoniella were reported, but the abundance of each was not mentioned.

The genus Apophorhynchus Williston, 1895 holds three species, none of which have been reported for the state of Pará (Marques \& Ale-Rocha 2005). Thus, A. amazonensis Prado, 1966 (Figure 6C), newly collected in this study, is a new occurrence for Pará, while in Brazil the species had been recorded only for Amazonas and Roraima (Marques-Costa \& Ale-Rocha, 2005, Ale-Rocha \& Alves 2006). This species seems to have a wide distribution in the central Brazilian Amazon, but as there are relatively few collections in western Pará, where the Belo Monte is located, this species has not been previously recorded for the state.

Ropalomera is the most species-rich genus of the Ropalomeridae, with about 16 described species (Kirst \& Ale-Rocha 2012). In this study four species were collected, but all with abundances equal to or less than two specimens.

Previous studies on Sarcophagidae community composition, abundance, and species richness undertaken in Amazonia have been based on specimens collected with carrion-baited traps mainly containing bovine lung (Esposito \& Linhares 2002, Amat et al. 2011, Souza et al. 2011, 2015), since many species have larvae that feed on decaying animal tissue (Pape \& Dahlem 2010). Nevertheless, fermenting fruit is also attractive for these flies, as Lopes (1975) observed, since the number of genera and species collected with fruit was substantial when compared to carrion. With bovine lung bait, Esposito \& Linhares (2002) collected five genera and seven species in the Caxiuanã region of Pará, and Souza et al. (2011) collected 10 genera and 23 species in the Urucu region of Amazonas, whereas fruit bait in Belo Monte attracted 11 genera and 22 species.

Most species attracted to fermenting fruit were also collected in studies using carrion (Esposito \& Linhares 2002, Amat et al. 2011, Souza et al. 2011, 2015). However, Lepidodexia bogotana (Enderlein, 1928) had not been reported in any previous study. Most species of the genus Lepidodexia, whose biology is known, are vertebrate and invertebrate parasites (Pape \& Dahlem 2010), and therefore are not generally collected with baited traps.

Although the community composition included many species shared with studies that used carrion, species abundances were different between types of bait. The most abundant species in the present study was Tricharaea occidua, which was also the most abundant in Souza et al. (2015). However, in studies by Esposito \& Linhares (2002) and Souza et al. (2011) the most abundant species were Peckia chrysostoma (Wiedemann, 1830) and Peckia lambens (Wiedemann, 1830), respectively, when rotting beef lung was utilized as bait. These two species were collected in this study, but with relative abundances below 4\% (Table 1). Souza et al. (2011) collected only two specimens of T. occidua, while Souza et al. (2015) captured 8.452 specimens, a difference that may be related to the type of sampled environment as well.

Ravinia effrenata is a new occurrence for the state of Pará, since in Brazil it was recorded only for Roraima, Maranhão, Minas Gerais, and Pernambuco (Lopes \& Leite 1990, Souza et al. 2015, Mello-Patiu et al. 2014, Barbosa 2019). This was the second most abundant species in this study, and no specimens were reported by Esposito \& Linhares (2002) or by Souza et al. (2011). This fact may be related to the kind of bait utilized, since in all other ecological studies performed in the 
Brazilian Amazon rotting bovine lung or fish were utilized (Esposito \& Linhares 2002, Amat et al. 2011, Souza et al. 2011).

The species Titanogrypa larvicida (Lopes, 1935) is also a new occurrence for the state of Pará, since this species had been registered only for Distrito Federal, Minas Gerais, Paraíba, Pernambuco, Rio Grande do Norte, Rio de Janeiro, and São Paulo (Pape 1996, Carvalho \& Linhares 2001, Barros et al. 2008, Moretti et al. 2008, Barbosa et al. 2009, Rosa et al. 2011, Alves et al. 2014, Barbosa 2019). This species has been reported in forensic studies using porcine and rat carcasses as baits (Barros et al. 2008, Moretti et al. 2008, Barbosa et al. 2009, Rosa et al. 2011), but fermenting fruit is also attractive as observed here.

The genus Oxysarcodexia Townsend, 1917 is one of the most characteristic taxa in ecological and forensic studies that use animal carcasses (Barros et al. 2008, Carvalho \& Linhares 2001, Moretti et al. 2008, Barbosa et al. 2009, Rosa et al. 201, Souza et al. 2011, 2015). This sarcophagid genus is one of the most abundant and widespread in the Neotropical region, but the biology of many species is still unknown (Pape \& Dahlem 2010). Larvae of this genus have been reared in vertebrate feces and in carrion (Pape \& Dahlem 2010). Despite this, they were also numerous in traps containing fermenting fruit bait in Belo Monte, since six species were collected, more than in the studies of Esposito \& Linhares (2002) and Souza et al. (2011), who used bovine lung as bait. Lopes (1975) obtained 11 species in butterfly traps baited with bananas, indicating that fermenting fruit is a good bait for species of this genus.

The most abundant Oxysarcodexia species in the present study was O. thornax (Wiedemann, 1830), which was the third most abundant sarcophagid species. In Souza et al. (2011), O. thornax was also the most abundant species, while in Souza et al. (2015) it was the second most abundant species of the genus. This species is widely distributed in the Americas and has been introduced in other mainland (Pape 1996) and is very common in all kinds of environments, including cities (Carvalho-Filho et al, in preparation). This fact suggests that it possesses wide ecological plasticity, allowing this species to explore many environments, where it is one of the most abundant flesh flies, and to consume various kinds of food, including rotting animal tissues, feces, and fermenting fruits.

The second most species-rich genus in the present study was Helicobia, with four species. In Souza et al. (2011) and Barros et al. (2008) only one species of this genus was collected and in low abundance. However, in Souza et al. (2015) seven species were obtained, indicating that animal carcasses and decomposing fruit are attractive for this genus. Helicobia aurescens (Townsend, 1927) is a new record for the Brazilian Amazon, since in Brazil it was recorded for Distrito Federal, Mato Grosso do Sul, Minas Gerais, Paraná, Pernambuco, Rio de Janeiro, and São Paulo (Pape 1996, Barros et al. 2008, Mello-Patiu et al. 2014, Barbosa 2019, Toma et al. 2020).

The genus Peckia, which is one of the most species-rich in the Neotropical region (Buenaventura \& Pape 2013), was the third genus with the most species (three species) collected in the present study (Table 1). In studies of Sarcophagidae from the Amazon and the Brazilian northeast, all of which used bovine lung as bait, this genus was the one with most species. Souza et al. (2015) obtained 11 species and Souza et al. (2015) 12 species. In addition, in other studies (Esposito \& Linhares 2002, Amat et al. 2011, Souza et al. 2011, 2015), some Peckia species, such as $P$. lambens and $P$. chrysostoma, were relatively abundant,

which was not observed in the present study. The greater abundance of Peckia species with bovine lung bait may be related to the larvae being predominantly necrophagous and requiring protein to complete their development (Pape \& Dahlem 2010).

The results shown in this study represent the first data on a saprophytic fly community in a poorly sampled and threated region of the Brazilian Amazon. Since the sampling was performed following a standardized protocol, the data shown here can be compared to other studies that follow the same protocol in other Amazonian regions. In addition, the new data can be utilized in faunal monitoring of the region under impact of Belo Monte hydroelectric dam.

\section{Acknowledgements}

The "Fundação Amazônia de Amparo a Estudos e Pesquisa" supported this study with a fellowship to author CLDQ. Marcelo Thalês elaborated the map. AB Viana-Junior receives a scholarship of postdoctoral grant by the Biodiversity Research Consortium BrazilNorway (BRC), Hydro-Alunorte (\#12/16 Ecological Interaction project).

\section{Author Contributions}

Camila Lorena Damasceno Queiroz: Contribution to manuscript preparation; contribution to critical revision, adding intellectual content.

Caroline Costa De-Souza: Contribution to manuscript preparation; data analysis and interpretation.

Hermes Fonseca de Medeiros: Contribution in the concept of the study; data collection; contribution to critical revision, adding intellectual content.

William Leslie Overal: Contribution to manuscript preparation; contribution to critical revision, adding intellectual content.

Arleu Barbosa Viana-Junior: Data analysis and interpretation; contribution to critical revision, adding intellectual content.

Fernando da Silva Carvalho-Filho: Contribution to manuscript preparation; contribution to critical revision, adding intellectual content.

\section{Conflicts of Interest}

The authors declare that they have no conflict of interest related to the publication of this manuscript.

\section{Ethics}

Specimens were collected under IBAMA / SISBio permit number $251 / 2013$.

\section{Data availability}

Data were compiled from the published literature, and appropriately cited in the text. Specimens deposited in the entomology collection of the Museu Paraense Emílio Goeldi will be registered in Specify and published on-line.

\section{References}


ACZÉL, M. 1961. A revision of the American Neriidae (Diptera, Acalyptratae). Stud. Entomol. 4:257-346.

ALE-ROCHA, R. \& ALVES, V.R. 2006. Descrição do macho de Apophorhynchus flavidus Williston e chave de identificação, baseada em machos, para espécies de Apophorhynchus Williston (Diptera, Ropalomeridae). Rev. Bras. Entomol. 50:352-354.

ALHO, C.J.R. 2011. Environmental effects of hydropower reservoirs on wild mammals and freshwater turtles in Amazonian: A review. Oecol. Austral. 15:593-604.

ALVES, A.C.F., SANTOS, W.E. \& CREÃO-DUARTE, A. 2014. Diptera (Insecta) de importância forense da região Neotropical. Entomotropica 29:77-94.

AMAT, E. 2010. Notes on necrophagous flies (Diptera: Calyptratae) associated with fish carrion in Colombian Amazon. Acta Amazon. 40:397-400.

AMAT, E., MARINHO, M.A.T. \& RAFAEL, J.A. A survey of necrophagous blowflies (Diptera: Oestroidea) in the Amazonas-Negro interfluvial region (Brazilian Amazon). Rev. Bras. Entomol. 60:57-62.

BARBOSA, T.M. 2019. Sarcophagidae (Diptera) no bioma caatinga: Revisão taxonômica do subgênero Titanogrypa (Cucullomyia) e avaliação do potencial de espécies como bioindicadoras de conservação ambiental. Tese de doutorado, Universidade Federal de Pernambuco, Recife.

BARBOSA, L.S., CUNHA, A.M., COURI, M.S. \& MAIA, V.C. 2014. Muscidae, Sarcophagidae, Calliphoridae e Mesembrinellidae (Diptera) da Estação Biológica de Santa Lúcia (Santa Teresa, Espírito Santo, Brasil). Bol. Mus. Biol. Mello Leitão 33:131-140.

BARBOSA, R.R., MELLO-PATIU, C.A., MELLO, R.P. \& QUEIROZ, M.M.C. 2009. New records of calyptrate dipterans (Fanniidae, Muscidae and Sarcophagidae) associated with the decomposition of domestic pigs in Brazil. Mem. Inst. Oswaldo Cruz 104:923-926.

BARONA, E., RAMANKUTTY, N., HYMAN, G. \& COOMES, O.T. 2010. The role of pasture and soybean in deforestation of the Brazilian Amazon. Environ. Res. Lett. 5:1-9.

BARROS, R.M., MELLO-PATIU, C.A. \& PUJOL-LUZ, J.R. 2008. Sarcophagidae (Insecta, Diptera) associados à decomposição de carcaças de Sus scrofa Linnaeus (Suidae) em área de Cerrado do Distrito Federal, Brasil. Rev. Bras. Entomol. 52:606-609.

BONATTO, S.R. 2001. Revisão e análise cladística de Mesembrinellidae stat. ver. (Diptera: Oestroidea). Tese de doutorado, Universidade Federal do Paraná, Curitiba.

BROWN, V.B., BORKENT, A., ADLER, P.A., AMORIM, D.S., BARBER, K., BICKEL, D., BOUCHER, S., BROOKS, S.E., BURGER, J., BURINGTON, Z. L., et al. 2018. Comprehensive inventory of true flies (Diptera) at a tropical site. Nat. Commun. 1:21.

BUCK, M. 2010. Neriidae. In Manual of Central American Diptera (B. V. BROWN, A. BORKENT, J. M. CUMMING, D.M. WOOD, N.E. WOODLEY \& M.A. ZUMBADO, eds.). NRC Research Press, Ottawa, p. 815-819.

BUENAVENTURA, E. \& PAPE, T. 2013. Revision of the New World genus Peckia Robineau- Desvoidy (Diptera: Sarcophagidae). Zootaxa 3622:1-87.

CARVALHO, L.M.L. \& LINHARES, A.X. 2001. Seasonality of insect succession and pig carcass decomposition in a natural forest area in southeastern Brazil. J. Forensic Sci. 46:604-608.

CARVALHO, C.J.B. \& MELLO-PATIU, C.A. 2008. Keys to the adults of the most common forensic species of Diptera in South America. Rev. Bras. Biol. 52:390-406.

CARVALHO-FILHO, F.S. \& ESPOSITO, M.C. 2008. Neriidae (Diptera: Schizophora) of the Brazilian Amazon: New records of genera and species, and key to species. Neotrop. Entomol. 37:58-62.

CARVALHO-FILHO, F.S. \& ESPOSITO, M.C. 2012. Revision of Argoravinia Townsend (Diptera: Sarcophagidae) of Brazil with the description of two new species. Zootaxa 3256:1-26.

COLWELL, R.K. 2013. EstimateS: Statistical estimation of species richness and shared species from samples. Version 9.0. Storrs, University of Connecticut. Available at: http://purl.oclc.org/ estimates. (last access in: 22/08/2017).
COLWELL, R.K. \& CODDINGTON, J.A. 1994. Estimating terrestrial biodiversity through extrapolation. Philos. Trans. R. Soc. B. 345:101-118.

ERWIN, T.L. 1991. An evolutionary basis for conservation strategies. Science 253:750-752.

ESPOSITO, M.C. \& LINHARES, A.X. 2002. Califorídeos e outros muscóides da Estação Cientifica Ferreira Penna. In Caxiuanã: populações tradicionais, meio físico \& diversidade biológica (P.L.B. LISBOA, ed.). Museu Paraense Emílio Goeldi, Belém, p.579-585.

ESPOSITO, M.C., SOUSA, J.R.P. \& CARVALHO-FILHO, F.S. 2010. Diversidade de Calliphoridae (Insecta: Diptera) na Base de Extração Petrolífera da Bacia do Rio Urucu, na Amazônia brasileira. Acta Amazon. 40:579-584.

FEARNSIDE, P.M. 2006. Dams in the Amazon: Belo Monte and Brazil's hydroelectric development of the Xingu River Basin. Environ. Manage. 38:16-27.

FERRAZ, A.C.P., GADELHA, B.Q. \& AGUIAR-COELHO, V.M. 2010. Effects of forest fragmentation on dipterofauna (Calliphoridae) at the Reserva Biológica do Tinguá, Nova Iguaçu, RJ. Braz. J. Biol. 70:55-63.

FONSECA, A., SOUZA JÚNIOR, C. \& VERÍSSIMO, A. 2015. Deforestation report for the Brazilian Amazon (January 2015) SAD. Imazon, Belém. Avaliable at: https://imazon.org.br/en/publicacoes/deforestation-reportfor-the-brazilian-amazon-january-2015-sad/ (last access in: 10/01/2020).

FREITAS, A.V.L., FRANCINI, R.B. \& BROWN JÚNIOR., K.S. 2003. Insetos como indicadores ambientais. In Métodos de estudos em biologia da conservação e manejo da vida silvestre (L. CULLEN JÚNIOR, C. VALLADARES-PADUA \& R. RUDRAN, eds.). Editora da Universidade Federal do Paraná, Curitiba, p.125-152.

GUIMARÃES, J.H. 1977. A systematic revision of the Mesembrinellidae, stat. nov. (Diptera, Cyclorrhapha). Arq. Zool. 29:1-109.

GOMES, R.L.C., SOUSA, J.R.P., CARVALHO-FILHO, F.S. \& ESPOSITO, M.C. 2013. Eficiência de três tipos de armadilhas na captura de moscas mesembrinelíneas (Diptera: Calliphoridae) na Floresta Nacional de Caxiuanã. In Caxiuanã: Paraíso ainda preservado: Meio físico \& diversidade biológica (P.L.B. LISBOA, ed.). Museu Paraense Emílio Goeldi, Belém, p.579-585.

IBANEZ-BERNAL, S. \& HERNANDEZ-ORTIZ, V. 2012. Ropalomeridae (ropalomerid flies). In Manual of Central American Diptera (B.V. BROWN, A. BORKENT, J.M. CUMMING, D.M. WOOD, N.E. WOODLEY \& M.A. ZUMBADO, eds.). NRC Research Press, Ottawa, p.1025-1030.

IBGE. 2012. Manual técnico da vegetação brasileira. Instituto Brasileiro de Geografia e Estatística, Rio de Janeiro. p.1-217.

KIM, K.C. 1993. Biodiversity, conservation and inventory: why insects matter. Biodivers. Conserv. 2:191-214.

KIRST, F.D. \& ALE-ROCHA, R. 2012. Taxonomic revision of the Amazonian species of Ropalomera Wiedemann, 1824 (Diptera: Ropalomeridae). Zootaxa 3151:1-27.

KOSMANN, C., MELlO, R.P., HARTERREITEN-SOUZA, E.S. \& PUJOL-LUZ, J.R. 2013. A list of current valid blow fly names (Diptera: Calliphoridae) in the Americas south of Mexico with key to the Brazilian species. EntomoBrasilis 6:74-85.

LOPES, H.S. 1939. Contribuição ao conhecimento do gênero Helicobia Coquillett (Dipt. Sarcophagidae). Rev. Entomol. 10:497-517.

LOPES, H.S. 1946. Contribuição ao conhecimento das espécies do gênero Oxysarcodexia Townsend, 1917 (Diptera, Sarcophagidae). Bol. Esc. Nac. Vet. 1:62-134.

LOPES, H.S. 1958. Descriptions of six new species of Retrocitomyia Lopes (Diptera, Sarcophagidae). Bol. Mus. Nac. 309:1-8.

LOPES, H.S. 1975. Sarcophagid flies (Diptera) from Pacatuba, State of Ceará, Brazil. Rev. Brasil. Biol. 34:271-294.

LOPES, H.S. \& LEITE, A.C.R. 1991. Notes on the male genitalia of species of Ravinia and Chaetoravinia (Diptera: Sarcophagidae). Mem. Inst. Oswaldo Cruz 86:95-101.

LOPES, H.S. \& TIBANA, R. 1987. On Oxysarcodexia (Diptera, Sarcophagidae), with descriptions of five new species, key, list and geographic distribution of the species. Rev. Bras. Biol. 47:329-347. 
LUJAN, N.K. \& CONWAY, K.W. 2015. Life in the fast lane: a review of rheophily in freshwater fishes. In Extremophile fishes (R. RIESCH, M. TOBLER \& M. PLATH, eds.). Springer International Publishing, New York, p.107-136.

MAGNUSSON, W.E., LIMA, A.P., LUIZÃO, R., LUIZÃO, F., COSTA, F.R.C., CASTILHO, C.V.E. \& KINUPP, V.F. 2005. RAPELD: Uma modificação do método de Gentry para inventários de biodiversidade em sítios para pesquisa ecológica de longa duração. Biota Neotrop. 5:1-6.

MARGULES, C.R. \& AUSTIN, M.P., eds. 1991. Nature conservation: cost effective biological surveys and data analysis. CSIRO Publishing, Canberra. p.1-207.

MARQUES, A.P.C. \& ALE-ROCHA, R. 2005. Revisão do gênero Willistoniella Mik, 1985 (Diptera, Ropalomeridae) da região Neotropical. Rev. Bras. Entomol. 49:210-227.

MARQUES, A.P.C., ALE-ROCHA, R. \& RONCHI-TELES, B. 2004. Flutuação populacional de Willistoniella Mik e Ropalomera Wiedemann (Diptera: Ropalomeridae) na Amazônia Central. Neotrop. Entomol. 33:661-664.

MARQUES-COSTA, A.P.C. \& ALE-ROCHA, R. 2005. Revisão do gênero neotropical Apophorhynchus Williston (Diptera, Ropalomeridae). Rev. Bras. Entomol. 49:512-521.

MARSHALL, S.A. 2012. Flies: The natural history and diversity of Diptera. Firefly Books, Richmont Hill, Ontario, Canada. p.1-616.

MEDEIROS, H.F. \& KLACZKO, L.B. 1999. A weakly biased Drosophila trap. Drosoph. Inf. Serv. 82:100-102.

MELlO-PATIU, C.A., PASETO, M.L., FARIA, L.S., MENDES, J. \& LINHARES, A.X. 2014. Sarchophagid flies (Insecta, Diptera) from pig carcasses in Minas Gerais, Brazil, with nine new records from the Cerrado, a threatened Neotropical biome. Rev. Bras. Entomol. 58:142-146.

MORETTI, T.C., RIBEIRO, O.B., THYSSEN, P.J. \& SOLIS, D.R. 2008. Insects on decomposing carcasses of small rodents in a secondary forest in southeastern Brazil. Eur. J. Entomol.105:691-696.

MORRISON, L.M., BLOCK, W. M., STRICKLAND, M.D., COLLIER, B.A. \& PETERSON, M.J. 2008. Inventory and monitoring studies. In Wildlife study design. (M.L. MORRISON, W.M. BLOCK, M.D. STRICKLAND, B.A. COLLIER \& M.J. PETERSON, eds.). Springer, New York. p.267-312.

OLIVEIRA, U., PAGLIA, A.P., BRESCOVIT, A.D., CARVALHO, C.J., SILVA, D.P., REZENDE, D.T., LEITE, F.S.F., BATISTA, J.A.N., BARBOSA, J.P.P.P., STEHMANN, J.R., ASCHER, J.S., VASCONCELOS, M.F., MARCO-JUNIOR, P., LOWENBERG-NETO, P., DIAS, P.G., FERRO, V.G., \& SANTOS, A.J. 2016. The strong influence of collection bias on biodiversity knowledge shortfalls of Brazilian terrestrial biodiversity. Divers. Distrib. 22:1232-1244.

PAPE, T. 1996. Catalogue of the Sarcophagidae of the world (Insecta: Diptera). Mem. Entomol., Internatl. 8:1-558.

PAPE, T. \& DAHLEM, G.A. 2010. Sarcophagidae. In Manual of Central American Diptera (B.V. BROWN, A. BORKENT, J.M. CUMMING, D.M. WOOD, N.E. WOODLEY \& M.A. ZUMBADO, eds.). NRC Research Press, Ottawa, p.1313-1335.

PRADO, A.P. 1966. Segunda contribuição ao conhecimento da família Rhopalomeridae (Diptera, Acalyptratae). Stud. Entomol. 8:209-268.

ROSA, T.A., BABATA, M.L.Y., SOUZA, C.M., SOUSA, D., MELLO-PATIU, C.A., VAZ-DE-MELLO, F.Z. \& MENDES, J. 2011. Arthropods associated with pig carrion in two vegetation profiles of Cerrado in the State of Minas Gerais, Brazil. Rev. Bras. Entomol. 55:424-434.

SABAJ PÉREZ, M. 2015. Where the Xingu bends and will soon break. Sci. Am. 103:395-403.

SALOMÃO, R.D.P., VIEIRA, I.C.G., SUEMITSU, C., ROSA, N.D.A., ALMEIDA, S.S., AMARAL, D. D. \& MENEZES, M.P.M. 2007. As florestas de Belo Monte na grande curva do rio Xingu, Amazônia Oriental. Bol. Mus. Para. Emílio Goeldi, Ciênc. Nat. 2:55-153.

SANTOS, A.J. 2003. Estimativas de riqueza em espécies. In Métodos de estudos em biologia da conservação e manejo da vida silvestre (L. CULLEN JÚNIOR, C. VALLADARES-PADUA \& R. RUDRAN eds.). Curitiba, Editora da Universidade Federal do Paraná, p.19-42.
SANTOS FRANCO, V., SOUZA, E.B., PINHEIRO, A.N., SILVA, D.T.S., AZEVEDO, F.T. \& CARMO, S.J.C. 2015. Evolução mensal da cota fluviométrica do rio Xingu em Altamira-PA associada aos eventos El Niño e La Niña. Ciênc. Nat. 37:104-109.

SEPÚLVEDA, T.A., PEREIRA-COLAVITE, A. \& CARVALHO, C.J.B. 2013a. Revision of the Neotropical genus Cerantichir (Diptera: Neriidae) with new records and a key to species. Rev. Colomb. Entomol. 39:125-131.

SEPÚlVEDA, T. A., WOLF, M.I. \& CARVALHO, C.J.B. 2013b. Revision of the Neotropical genus Eoneria (Diptera: Neriidae) with description of a new species from Colombia. Zootaxa 3636:245-256.

SEPÚLVEDA, T.A., WOLF, M.I. \& CARVALHO, C.J.B. 2014. Revision of the New World genus Glyphidops Enderlein. Zootaxa 3785:139-174.

SILVA, J.M.C. \& GARDA, A.A. 2011. Padrões e processos biogeográficos na Amazônia. In Biogeografia da América do Sul: padrões e processos (C.J.B. CARVALHO \& A.B. ALMEIDA, eds.). Editora Roca, São Paulo, p.189-197.

SOUSA, J.R.P., ESPOSITO, M.C. \& CARVALHO-FILHO, F.S. 2010. A fauna de califorídeos (Díptera) das matas e clareiras com diferentes coberturas vegetais da Base de Extração Petrolífera, bacia do Rio Urucu, Coari, Amazonas. Rev. Bras. Entomol. 54:270-276.

SOUSA, J.R.P., ESPOSITO, M.C. \& CARVALHO-FILHO, F.S. 2011. Composition, abundance and richness of Sarcophagidae (Diptera: Oestroidea) in forests and forest gaps with different vegetation cover. Neotrop. Entomol. 40:20-27.

SOUSA, J.R.P., ESPOSITO, M.C. \& CARVALHO-FILHO, F.S. 2015. Distribution and abundance of necrophagous flies (Diptera: Calliphoridae and Sarcophagidae) in Maranhão, northeastern Brazil. J. Insect Sci. 15:1-10.

SOUSA-JÚNIOR, W.C., REID, J. \& LEITÃO, N.C.S. 2006. Custos e benefícios do complexo hidrelétrico Belo Monte: uma abordagem econômicoambiental. Conservation Strategy Fund (CSF), Lagoa Santa, Minas Gerais. Disponível em: http://www.conservationstrategy.org

STEYSKAL, G.C. 1968. Family Neriidae. [Part] 49. In A Catalogue of the Diptera of the Americas south of the United States (N. PAPAVERO, ed.). Departamento de Zoologia, São Paulo, p.1-7.

TIBANA, R. \& XEREZ, R. 1985. Uma nova espécie de Retrocitomyia Lopes, 1982, (Diptera, Sarcophagidae). Rev. Brasil. Biol. 45:485-488.

TÓFOLI, R.M., DIAS, R.M., ALVES, G.H.Z., HOEINGHAUS, D.J., GOMES, L.C., BAUMGARTNER, M T. \& AGOSTINHO, A.A. 2017. Gold at what cost? Another megaproject threatens biodiversity in the Amazon. Perspect. Ecol. Conserv. 15, 2.

TOMA, R., KOLLER, W.W., MELLO-PATIU, C.A. \& MELLO, R.L. 2020. New records of Sarcophagidae (Insecta: Diptera) collected in Cerrado fragments in the municipality of Campo Grande, Mato Grosso do Sul state, Brazil. EntomoBrasilis 13:e0873.

TONETTI, V.R., REGO, M.A., LUCA, A.C., DEVELEY, P.F., SCHUNCK, F. \& SILVEIRA, L.F. 2017. Historical knowledge, richness and relative representativeness of the avifauna of the largest native urban rainforest in the world. Zoologia 34:e13728.

VANE-WRIGHT, R.I., HUMPHREYS, C.J. \& WILLIAMS, P.H. 1991. What to protect-systematics and the agony of choice. Biol. Conserv. 55:235-254.

VIEIRA, I.C.G., TOLEDO, P.M., SILVA, J.M.C. \& HIGUCHI, H. 2008. Deforestation and threats to the biodiversity of Amazonia. Braz. J. Biol. 68:949-956.

WOLFF, M., RAMOS-PASTRANA, Y. \& PUJOL-LUZ, J.R. 2012. Description of the male of Laneella perisi (Mariluis) (Diptera: Calliphoridae) n. comb. Neotrop. Entomol. 42:58-62.

Received: $15 / 04 / 2020$

Revised: 06/10/2020

Accepted: 20/10/2020

Published online: 06/01/2021 